\title{
PENGARUH PERSISTENSI DIRI DAN KEBIASAAN BELAJAR TERHADAP KEMAMPUAN PEMECAHAN MASALAH MATEMATIKA DI SMP SWASTA JAKARTA TIMUR
}

\author{
Mohamad Lutfi Nugraha \\ Dosen Program Studi Teknik Informatika Universitas Indraprasta PGRI \\ Email: muhammadlutfinugraha@yahoo.co.id
}

\begin{abstract}
Abstrak
Tujuan Penelitian adalah untuk mengetahui apakah terdapat pengaruh tidak langsung persistensi diri dan kebiasaan belajar terhadap kemampuan pemecahan masalah matematika secara bersama-sama pada semester genap tahun pelajaran 2013/2014. Sampel yang digunakan di dalam penelitian ini diambil secara sederhana (simple random sampling) dengan mengambil sampel 40 siswa. Sebelumnya instrumen telah diuji validitas, realibilitas, taraf kesukaran, dan daya beda soal sehingga terlebih dahulu dilakukan uji persyaratan yaitu uji normalitas menggunakan uji Homogenitas serta uji linieritas dengan menggunakan uji analisis jalur. Hasil dari analisis jalur : 1) tidak terdapat pengaruh langsung persistensi diri terhadap kemampuan pemecahan masalah matematika. Dengan kontribusinya sebeser $0,98 \%$; 2) tidak terdapat pengaruh langsung kebiasaan belajar terhadap kemampuan pemecahan masalah matematika. Kontribusinya sebesar $15,87 \%$; 3)terdapat pengaruh langsung persistensi diri terhadap kebiasaan belajar. Kontribusi langsung persistensi diri $\left(\mathrm{X}_{1}\right)$ terhadap Kebiasaan belajar $\left(\mathrm{X}_{2}\right)$ sebesar $0,987^{2}$ x $100 \%=97,41 \%$.: 4) tidak terdapat pengaruh tidak langsung yang signifikan persistensi diri terhadap kemampuan pemecahan masalah matematika melalui kebiasaan belajar.
\end{abstract}

Kata Kunci : Persistensi diri, Kebiasaan Belajar, Kemampuan Pemecahan Masalah Matematika.

\section{PENDAHULUAN}

Pendidikan merupakan persoalan yang pelik, namun semuanya merasakan bahwa pendidikan merupakan tugas Negara yang teramat penting, disisi lain pendidikan merupakan tanggung jawab semua individual yang peduli terhadap kelangsungan hidup masyarakat untuk membangun masyarakat yang lebih maju dan terealisasi sehingga dapat memperbaiki keadaan masyarakat Indonesia khususnya dan dunia pada umumnya, tentu kuncinya ada di dalam pendidikan salah satunya mempelajari bidang matematika.

Keberhasilan dan kegagalan siswa dalam belajar tersebut dipengaruhi oleh beberapa faktor. Untuk menyatakan bahwa suatu proses belajar dapat dikatkan berhasil, setiap guru memiliki pandangan masing-masing sesuai dengan filsafatnya. Namun untuk menyamakan persepsi sebaiknya kita berpedoman pada kurikulum yang berlaku pada saat ini yang telah disempurnakan, antara lain yang telah dikemukakan oleh Bahri dan Zain (2006 : 119) bahwa suatu proses belajar tentang suatu bahan pegajaran dinyatakan berhasil apabila tujuan instruksional khusus (TIK)-nya dapat tercapai. Kemampuan pemecahan masalah matematika dapat dipengaruhi oleh beberapa faktor, dimana faktorfaktor tersebut saling berkaitan dan saling mempengaruhi satu sama lain. Salah satu faktornya adalah kebiasaan belajar.

Keberhasilan suatu proses belajar juga tergantung dari subjek dan objek dari pembelajaran yaitu kepribadian siswanya itu sendiri. Apabila kepribadian siswa terus berkembang akan memudahkan untuk mencapai keberhasilan belajar. Ciri dari seorang siswa yang berkembang yaitu memiliki persistensi diri dalam belajar.Yang berarti mempunyai ketetapan dan berulang secara konstan dalam dirinya atau kepribadiaannya.Bukan berarti bahwa tidak terjadi perubahan, melainkan terdapat kecendrungan bagi beberapa ciri tetap, tak berubah, atau mempunyai bentuk yang tak 
relatif tak berubah bahkan juga terhadap latihan dan tekanan sosial. Allport yang dikutip Elizabeth (1978:242) menekankan bahwa: "Kepribdiaan adalah susunanya yang relatif tetap dan unik".

Kemampuan Pemecahan Masalah Matematika adalah suatu sikap seorang siswa yang mampu dan bisa dalam memberikan solusi dan menyelesaikan masalah yang muncul dalam pelajaran matematika.Satu masalah biasanya memuat suatu situasi yang mendorong seseorang untuk menyelesaikannya akan tetapi tidak bagaimana cara memecahkan masalah tersebut.

Banyak fakor-faktor yang mempengaruhi Kemampuan Pemecahan matematika siswa baik berasal dari dalam diri siswa ataupun diluar diri siswa.Salah satu faktor yang mempengaruhinya yaitu kebiasaan belajar dari dalam diri siswa tersebut. Kebiasaan belajar itu sendiri merupakan cerminan dari cara belajar siswa tersebut didalam kehidupan sehari-hari baik disekolah maupun dirumah.Pernyataan Eysenk yang menyebutkan bahwa kebiasaan adalah pola tingkah laku, kondisi atau situasi tertentu yang terbentuk melalui proses belajar..Kebiasaan belajar yang dilakukan peserta didik dari mulai perencanaan dan kedisiplinan belajar, prosedur belajar, ketrampilan belajar serta strategi belajar dapat memberikan hasil belajar baik jika komponen-komponen tersebut dilaksanakan dengan baik pula.

Persistensi diri dan kebiasaan belajar dalam setiap siswa perlu ditingkatkan untuk menunjang proses berhasilnya pembelajaran dalam matematika. Disinilah peran guru yang sangat potensial untuk meningkatkan persistensi diri atau ketetapan dan kebiasaan belajar dari siswa dalam belajar matematika itu sendiri disamping faktor eksternal juga diperlukan. Tentunya pasti akan ada perbedaaan antara siswa yang mempunyai persistensi diri dan kebiasaan belajar yang baik serta siswa yang tidak mempunyai persistensi diri dan kebiasaan belajar dalam keberhasilan belajar yaitu pemecahan masalah, khususnya matematika.

\section{TINJAUAN PUSTAKA}

\section{Kemampuan Pemecahan Masalah Matematika}

Hakikat matematika menurut Soedjadi dalam Suherman (2010:1), "yaitu memiliki objek tujuan abstrak, bertumpu pada kesepakatan, dan pola pikir yang deduktif”. Dimana masih memerlukan pembelajaran matematika yang abstrak dengan menggunakan alat bantu berupa media dan alat peraga agar dapat memperjelas apa yang disampaikan oleh guru sehingga lebih cepat dimengerti siswa.

Matematika lebih tepat digunakan dari pada ilmu pasti, karena memang benarlah bahwa dengan menguasai matematika orang akan belajar mengerti jalan pikirannya dan sekaligus manambah kepandaiannya.Terdapat banyak masalah pada diri siswa dalam kemampuannya menyelesaikan masalah matematika.

Masalah adalah suatu kendala atau persoalan yang harus dipecahkan dengan kata lain masalah merupakan kesenjangan antara kenyataan dengan suatu yang diharapkan dengan baik, agar tercapai tujuan dengan hasil yang maksimal.

Satu masalah biasanya memuat suatu situasi yang mendorong seseorang untuk menyelesaikannya akan tetapi tidak bagaimana cara memecahkan masalah tersebut. Jika seorang guru memberikan suatu masalah kepada siswa dan siswa tersebut langsung menyelesaikannya dengan baik dan benar maka soal tersebut bukan masalah.Memecahkan suatu masalah merupakan suatu aktivitas dasar bagi manusia.Kenyataan menunjukkan, sebagian besar kehidupan kita adalah berhadapan dengan masalah-masalah.Kita perlu mencari penyelesaiannya. Bila kita gagal dengan 
suatu cara untuk menyelesaikan suatu masalah. Kita harus mencoba menyelesaiakannya dengan cara lain. Kita harus berani menghadapi masalah untuk menyelesaiakannya.

Munandar menyatakan (2003 : 206) Pemecahan masalah secara kreatif meliputi lima langkah : menemukan fakta, menemukan masalah, menemukan gagasan, menemukan solusi, dan menemukan penerimaan.

Berdasarkan uraian di atas, Kemampuan Pemecahan MasalahMatematika adalahsuatu keterampilan siswa untuk mencari solusi dari persoalan -persoalan atau masalah - masalah yang muncul dari ilmu matematika.

\section{Kebiasaan Belajar}

Kebiasaan belajar merupakan proses pendidikan di Sekolah. Ini berarti bahwa berhasil tidaknya pencapaian tujuan pendidikan banyak bergantung kepada bagaimana pencapaian taksonomi pendidikan yang di alami siswa yang mencakup aspek kognitif, afektif dan psikomotorik. Dalam suatu lembaga kependidikan keberhasilan proses pembelajaran dapat dilihat juga dari kemampuan pemecahan masalah matematika yang dicapai oleh peserta didik. Fatimah (2011 : 95) mengungkapkan dalam majalah ilmiah mengatakan dalam konteks pembelajaran ada beberapa tolak ukur yang dapat digunakan untuk mengetahui kemampuan pemecahan masalah siswa . salah satunya adalah prestasi belajar yang mengacu pada pencapaian taksonomi pendidikan yaitu kognitif, afektif dan psikomotorik

Kebiasaan yang baik merupakan perilaku yang relatif menetap dalam menunjang kegiatan belajar yang berdampak pada hasil yang baik pula karena terdapat kesesuaian antara yang dilakukan siswa dengan pola-pola perilaku yang dituntut dalam proses belajar. Kebiasaan belajar menurut Syamsu Yusuf (2004:60) adalah perilaku (kegiatan) belajar yang relatif menetap, karena sudah berulang-ulang (rutin) dilakukan, baik cara, strategi belajar, maupun dalam pendekatan yang digunakan dalam belajar.

Lebih lanjut Gie (2002:61) juga mengatakan cara seseorang melakukan kegiatan belajar dibentuk oleh seperangkat kebiasaan sehari-hari yang dilakukan dalam belajar sebelumnya, didorong seperangkat motivasi untuk berprestasi secara memadai serta seperangkat kematangan emosi pribadi yang mendasari dalam hidup pribadinya. Kebiasaan atau cara belajar yang digunakan seorang siswa turut menentukan hasil belajar yang diharapkan. Cara yang efektif akan membawa hasil yang memuaskan, sedangkan cara yang tidak sesuai akan menyebabkan belajar itu kurang berhasil. Kebiasaan belajar yang efektif ditandai oleh: (1) pembuatan jadwal belajar dan pelaksanaannya; (2) pengutamaan pengertian dan pemahaman; (3) rajin membaca buku-buku pelajaran; (4) mengulang pelajaran secara teratur; (5) gairah dalam belajar; (6) kemampuan berdiskusi; (7) rajin bertanya. Kebiasaan belajar yang efektif hanya mungkin dimiliki dan dikuasai apabila sejak awal siswa telah dibiasakan belajar menurut cara-cara yang tepat. Sikap dan kebiasaan-kebiasaan termasuk salah satu aspek dari karakteristik psikologis yang digolongkan dalam kemampuan non intelektual

\section{Persistensi Diri}

Allport dalam Elizabeth (1978 : 242) menjelaskan istilah persistensi berarti "ketetapan" dan "berulang secara konstan", bukan berarti tidak terjadi perubahan. Tetapi artinya bahwa terdapat kecendrungan bagi beberapa ciri untuk tetap, tak berubah, atau mempunyai bentuk yang relatif tak berubah bahkan juga terhadap latihan dan tekanan sosial.Allport juga menekankan fakta penting mengenai kepribadiaan ialah susunannya yang relatif tetap dan unik. 
Sebagai contoh, anak yang sebagai bayi menunjukan iritabilitas, akan menunjukan ciri yang sama dengan bertambahnya usia, walaupun iritabilitas mereka mungkin agak dimodifikasi dan agak berkurang sebagai hasil tekanan lingkungan. Anak yang selalu diladeni orang tua dan anggota keluarga lain sering mempunyai dorongan berprestasi yang lemah. Akibanya, mereka mengembangkan kebiasaan bekerja di bawah kemampuan dan berprestasi rendah dalam hal apa sajayang mereka lakukan. Kecuali jika kondisi lingkungan atau harga diri memberi mereka motivasi yang diperlukan untuk menggunakan potensi bawaannya semaksimal mungkin, kecendrungan mereka untuk berprestasi rendah akan menetap.

Persistensi identik dengan konsistensi, kedua-duanya saling berhubungan satu sama lain. Persistensi merupakan suatu perilaku yang berhubungan dengan kepribadian.Untuk mencapai tujuan yang diharapkan memerlukan persistensi dari sejak dini.apabila sejak dini diterapkan persistensi kepribadiaan dengan ranah yang positif maka hasilnya akan terus bersifat positif.

\section{METODOLOGI PENELITIAN}

Secara umum penelitian ini bertujuan untuk mengetahui apakah terdapat pengaruh tidak langsung persistensi diri dan kebiasaan belajar terhadap kemampuan pemecahan masalah matematika di Sekolah Menengah Pertama Swasta Jakarta Timur.Penelitian dilaksanakan selama 4 bulan, dimulai bulan Mei sampai dengan bulan Agustus 2014.Penelitian ini menggunakan survey dengan teknik kausal.Adapaun data dianalisis dengan analisis jalur (path analysis). Populasi dalam penelitian ini adalah seluruh siswa SMP Al-Qalam dan SMP Uswatun Hasanah, dengan sampel 40 siswa.Teknik sampling dalam peneltian ini adalah Simple Random sampling. Teknik pengumpulan data menggunakan instrument berupa angket dan soal ulangan. Desain penelitian diuraikan sesuai diagram pada gambar 1, yang menggambarkan pengaruh langsung dan tidak langsung persistensi diri, kebiasaan belajar, dan kemampuan pemecahan masalah matematika.

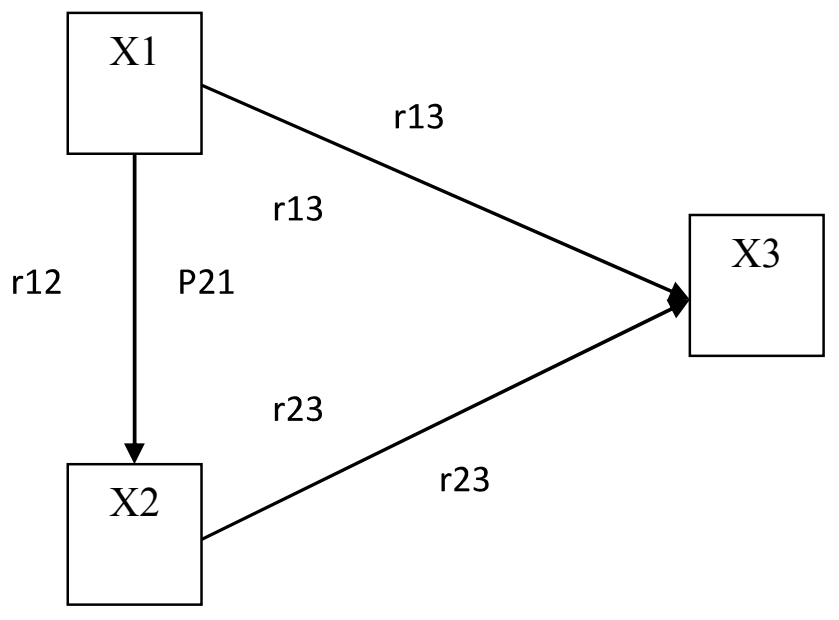

Gambar 1. Paradigma Penelitian $\mathrm{X}_{1}, \mathrm{X}_{2}, \mathrm{X}_{3}$

$\mathrm{X}_{1} \quad$ : Peristensi diri

$\mathrm{X}_{2} \quad$ : Kebiasaan Belajar

$\mathrm{X}_{3} \quad$ : Kemampuan Pemecahan Masalah Matematika 


\section{HASIL DAN PEMBAHASAN}

\section{Hasil Penelitian}

Dalam penelitian ini hipotesis akan diuji dengan menggunakan Analisis Jalur (Path Analysis). Untuk hal tersebut peneliti menyusun model hubungan antar variabel berdasarkan kerangka berfikir yang dikembangkan. Untuk keperluan tersebut peneliti menyusun diagram jalur sebgai berikut :

\section{Analisis Korelasi}

Analisis korelasi digunakan untuk mencari koefisien korelasi, yang selanjutnya koefisien korelasi tersebut akan digunakan untuk menentukan koefisien jalur. Dalam melakukan analisis korelasi, peneliti menggunakan SPSS 20 sebagai alat bantu dengan hasil sebagai berikuit :

Tabel 1. Koefisien Korelasi Correlations

\begin{tabular}{|c|c|c|c|c|}
\hline & & $\begin{array}{l}\text { Kemampuan } \\
\text { Pemecahan } \\
\text { Masalah } \\
\text { Matema fika } \\
\end{array}$ & $\begin{array}{l}\text { Persist } \\
\text { ensi } \\
\text { Din }\end{array}$ & $\begin{array}{l}\text { Kebiasa } \\
\text { an } \\
\text { Belajar }\end{array}$ \\
\hline \multirow{3}{*}{$\begin{array}{l}\text { Pearson } \\
\text { Correlation }\end{array}$} & $\begin{array}{l}\text { Kemampuan Pemecahan } \\
\text { Masalah Ma tematika }\end{array}$ & 1.000 & -.147 & -.178 \\
\hline & Persistensi Diñ & -147 & 1.000 & .987 \\
\hline & $\begin{array}{l}\text { Kebiasaan Belajar } \\
\text { Kemampuan Pemecahan } \\
\text { Masalah Ma tematika }\end{array}$ & $\begin{array}{l}-178 \\
.\end{array}$ & $\begin{array}{l}.987 \\
.183\end{array}$ & $\begin{array}{l}1.000 \\
.136\end{array}$ \\
\hline \multirow{2}{*}{ Sig. (1-tailed) } & $\begin{array}{l}\text { Persistensi Diñ } \\
\text { Kebiasaan Belajar }\end{array}$ & $\begin{array}{l}.183 \\
.136\end{array}$ & .000 & .000 \\
\hline & $\begin{array}{l}\text { Kemampuan Pemecahan } \\
\text { Masalah Matematika }\end{array}$ & 40 & 40 & 40 \\
\hline \multirow{2}{*}{$\mathrm{N}$} & Persistensi Din & 40 & 40 & 40 \\
\hline & Kebiasaan Belajar & 40 & 40 & 40 \\
\hline
\end{tabular}

\section{RANGKUMAN HASIL ANALISIS KORELASI (Koefisien Korelasi)}

$\begin{array}{llll}\text { Hubgungan antar variabel } & \text { Korelasi } & \text { Nilai } \\ \begin{array}{l}\text { Persistensi diri dengan kemampuan } \\ \text { pemecahan masalah matematika }\end{array} & r_{13} & -0,147 \\ \begin{array}{l}\text { Kebiasaan belajar dengan kemampuan } \\ \text { pemecahan masalah matematika }\end{array} & & \\ \begin{array}{l}\text { Persistensi diri dengan kebiasaan belajar } \\ r_{23}\end{array} & -0,178 \\ & r_{12} & 0,987\end{array}$

\section{Menentukan Koefisien Jalur Berdasarkan Koefisien Korelasi}

Untuk menentukan Koefisien jalur berdasarkan koefisien korelasi menggunakan SPSS 20, maka dapat dilihat pada tabel berikut:

Tabel 2. Koefisien Jalur p21

Coefficients $^{\mathrm{a}}$

\begin{tabular}{|l|l|l|l|l|l|}
\hline \multirow{2}{*}{ Model } & \multicolumn{2}{|l|}{$\begin{array}{l}\text { Unstandardized } \\
\text { Coefficients }\end{array}$} & $\begin{array}{l}\text { Standardized } \\
\text { Coefficients }\end{array}$ & T & \multirow{2}{*}{ Sig. } \\
\cline { 2 - 4 } & $\mathrm{B}$ & Std. Error & Beta & & \\
\hline (Constant) & 3.479 & 1.939 & & 1.794 & .081 \\
Persistensi Diri & 1.043 & .028 & $\mathrm{p}_{21}=.987$ & 37.553 & .000 \\
\hline
\end{tabular}

a. Dependent Variable: Kebiasaan Belajar 
Tabel 3. Koefisien Jalur p31 dan p32

Coefficients $^{\mathrm{a}}$

\begin{tabular}{|l|l|l|l|l|l|}
\hline \multirow{2}{*}{ Model } & \multicolumn{2}{|l|}{$\begin{array}{l}\text { Unstandardized } \\
\text { Coefficients }\end{array}$} & $\begin{array}{l}\text { Standardized } \\
\text { Coefficients }\end{array}$ & T & Sig. \\
\cline { 2 - 4 } & $\mathrm{B}$ & Std. Error & Beta & & \\
\hline (Constant) & 79.382 & 8.550 & & 9.284 & .000 \\
Persistensi Diri & .812 & .725 & $\mathrm{p}_{31}=.099$ & 1.119 & .270 \\
Kebiasaan Belajar & -.883 & .687 & $\mathrm{p}_{32=-0.263}$ & -1.285 & .207 \\
\hline
\end{tabular}

a. Dependent Variable: Kemampuan Pemecahan Masalah Matematika

\section{Memasukan Angka - Angka Koefisien Korelasi dan Koefisien Jalur Ke dalam Model Analisis Jalur}

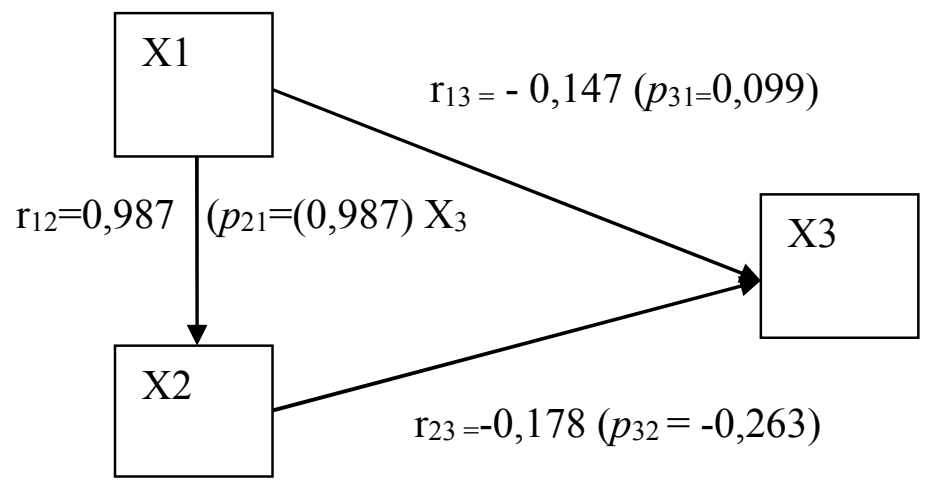

\section{Diagram koefisien korelasi dan koefisien jalur}

Keterangan:

Angka diluar kurung adalah koefisien korelasi dan angka di dalam kurung adalah koefisien jalur.

\section{Pengujian Keberartian Koefisien Analisis Jalur}

Sujana (2008 : 302) menyatakan bahwa, " jika koefisien jalur rendah di bawah 0,05 maka jalur tersebut dianggap tidak signifikan dan dapat dihilangkan. Berdasarkan perhitungan yang didasarkan oleh koefisien korelasi diperoleh koefisien jalur, koefisien jalur menunjukan kuatnya pengaruh variabel independen terhadap variabel dependen.

\section{Pengujian Hipotesis Kesatu}

$\mathrm{H}_{0}$ : Tidak terdapat pengaruh langsung signifikan Persistensi diri $\left(\mathrm{X}_{1}\right)$ terhadap

Kemampuan Pemecahan Masalah Matematika $\left(\mathrm{X}_{3}\right)$.

$\mathrm{H}_{1}$ : Terdapat pengaruh langsung signifikan Persistensi diri

$\left(\mathrm{X}_{1}\right)$ terhadap Kemampuan Pemecahan Masalah Matematika $\left(\mathrm{X}_{3}\right)$.

Uji hipotesis kesatu ini dapat diselesaikan dengan menggunakan SPSS 20, dapat dilihat pada tabel 3 di atas sehingga di dapat :

Untuk $\alpha=0,05$ dan $\mathrm{dk}=\mathrm{n}-\mathrm{k}-1=40-2-1=37$ pada uji dua pihak diperoleh nilai $t_{\text {tabel }}=t_{t}=2,042$, Karena nilai $t_{h}<t_{t}(1,119<2,042)$ maka $H_{0}$ diterima dan disimpulkan tidak terdapat pengaruh langsung yang signifikan Persistensi diri Terhadap Kemampuan Pemecahan Masalah Matematika. 


\section{Pengujian Hipotesis Kedua}

$\mathrm{H}_{0}$ : Tidak terdapat pengaruh langsung signifikan Kebiasaan belajar $\left(\mathrm{X}_{2}\right)$ terhadap

Kemampuan Pemecahan Masalah Matematika $\left(\mathrm{X}_{3}\right)$

$\mathrm{H}_{1}$ : Terdapat pengaruh langsung signifikan Kebiasaan belajar $\left(\mathrm{X}_{2}\right)$ terhadap

Kemampuan Pemecahan Masalah Matematika $\left(\mathrm{X}_{3}\right)$

Uji hipotesis kesatu ini dapat diselesaikan dengan menggunakan SPSS 20, dapat dilihat pada tabel 4 sehingga didapat :

Untuk $\alpha=0,05$ dan $\mathrm{dk}=\mathrm{n}-\mathrm{k}-1=40-2-1=37$ pada uji dua pihak diperoleh nilai $\mathrm{t}_{\text {tabel }}=\mathrm{t}_{\mathrm{t}}=2,042$, Karena nilai $\mathrm{t}_{\mathrm{h}}<\mathrm{t}_{\mathrm{t}}(-1,285<2,042)$ maka $\mathrm{H}_{0}$ diterima dan disimpulkan tidak terdapat pengaruh langsung signifikan Kebiasaan Belajar Terhadap Kemampuan Pemecahan Masalah Matematika

\section{Pengujian Hipotesis Ketiga}

$\mathrm{H}_{0}$ : Tidak terdapat pengaruh langsung signifikan Persistensi diri $\left(\mathrm{X}_{1}\right)$ terhadap

Kebiasaan belajar $\left(\mathrm{X}_{2}\right)$

$\mathrm{H}_{1}$ : Terdapat pengaruh langsung signifikan Persistensi diri $\left(\mathrm{X}_{1}\right)$ terhadap Kebiasaan belajar $\left(\mathrm{X}_{2}\right)$

Uji hipotesis kesatu ini dapat diselesaikan dengan menggunakan SPSS 20, dapat dilihat pada tabel 4.15 di atas maka didapat hasilnya sebagai berikut : Untuk $\alpha=0,05$ dan $\mathrm{dk}=\mathrm{n}-\mathrm{k}-1=40-2-1=37$ pada uji dua pihak diperoleh nilai $\mathrm{t}_{\text {tabel }}=\mathrm{t}_{\mathrm{t}}=2,042$

Karena nilai $\mathrm{t}_{\mathrm{h}}>\mathrm{t}_{\mathrm{t}}(37,553>2,042) \mathrm{maka}_{\mathrm{H}}$ diterima dan disimpulkan terdapat pengaruh langsung signifikan Persistensi diri Terhadap Kebiasaan belajar.

\section{Pengujian Hipotesis Keempat}

$\mathrm{H}_{0}$ : Tidak terdapat pengaruh tidak langsung signifikan Persistensi Diri terhadap

Kemampuan Pemecahan Masalah Matematika melalui Kebiasaan belajar

$\mathrm{H}_{1}$ : Terdapat pengaruh tidak langsung signifikan Persistensi diri terhadap Kemampuan Pemecahan Masalah Matematika melalui Kebiasaan belajar

Berdasarkan analisis jalur diketahui bahwa koefisien jalur variabel persistensi diri terhadap kemampuan pemecahan masalah matematika melalui kebiasaan belajar $p_{123}=$ $p_{12} \times p_{32}=0,987 \times-0,263=-0,25662$. Jika dibandingkan dengan nilai $p_{31}$ maka nilai $p_{123}$ $=-0,246581<p_{31}=0,099$. Hal ini mengintreprestasikan bahwa variabel intervening tidak berpengaruh secara signifikan terhadap kemampuan pemecahan masalah matematika.

Dari dari data mentah dan dengan bantuan perhitungan dengan bantuan spss 20 dan excel diperoleh :

$$
\begin{aligned}
S g & =\sqrt{\frac{\left(n_{21}-1\right) S_{21}^{2}+\left(n_{31}-1\right) S_{32}^{2}}{\left(n_{21}+n_{32}-2\right)}} \\
S g & =\sqrt{\frac{(40-1)(0,028)^{2}+(40-1)(0,687)^{2}}{40+40-2}} \\
S g & =0,2363
\end{aligned}
$$

Maka diperoleh nilai $t_{\mathrm{h}}$ sebagai berikut :

$\mathrm{t}_{\mathrm{h}}=\frac{p_{321}}{0,2363}$

$\mathrm{t}_{\mathrm{h}}=\frac{-0,25662}{0,2363}$

$\mathrm{t}_{\mathrm{h}}=-1,0859$ 
Untuk $\alpha=0,05$ dan $\mathrm{dk}=40-2-1=37$ pada uji dua pihak diperoleh nilai $\mathrm{t}_{\text {tabel }}=$ 2,042, Karena nilai $\mathrm{t}_{\mathrm{h}}<\mathrm{t}_{\mathrm{t}}(-1,0859<2,042)$ maka $\mathrm{H}_{0}$ diterima dan disimpulkan tidak terdapat pengaruh tidak langsung yang signifikan persistensi diri terhadap kemampuan pemecahan masalah matematika melalui kebiasaan belajar. Hal ini menunjukan bahwa besarnya pengaruh persistensi diri terhadap kemampuan pemecahan masalah matematika dan pengaruh kebiasaan belajar terhadap kemampuan pemecahan masalah matematika tidak memiliki perbedaan yang berarti.

\section{DAFTAR PUSTAKA}

Arikunto, Suharsimi. 2006. Prosedur Penelitian. Jakarta: Rineka Cipta.

Bahri dan Zain. 2006. Teori-teori Belajar. Jakarta : Erlangga.

Djamarah, Syaiful Bahri. 2002. Psikologi Belajar. Jakarta: Rineka Cipta.

Elfiky, Ibrahim. 2008. Terapi Berfikir Positif. Penerbit : Zansan.

Fatimah. 2011. Faktor Penentu Obyektivitas dan Kreativitas. Majalah Ilmiah Edisi Maret-April 2011. Sekeretariat LPPM UNINDRA.

Heruman. 2010. Belajar dan Pembelajaran. Jakarta : Erlangga

Muhibbin. 2003. Psikologi Belajar. Jakarta: Raja Grafindo Persada.

Munandar, Hutami. 2003. Pengembangan Kreativitas Anak Berbakat. Jakarta : Rineka Cipta

Nasution dan Thomas. 2009. Buku Penuntun Membuat Tesis, Skripsi, Disertasi, Makalah. Jakarta : Bumi Aksara

Riduwan. 2006. Belajar Mudah Penelitian untuk Guru Karyawan dan Peneliti Pemula. Bandung: Alfabeta.

Slameto. 2003. Belajar dan Faktor-faktor yang Mempengaruhinya. Jakarta: Rineka Cipta.

Sudjana, Nana. 2004. Penilaian Hasil Proses Belajar Mengajar. Bandung: Remaja Rosdakarya.

Supardi, U. S. 2012. Aplikasi Statistika Dalam Peneltian. Jakarta : Ufuk Press 